821.163.41-32.09

https://doi.org/10.18485/msc.2018.47.2.ch1

Gabriella SCHUBERT*

Friedrich-Schiller-Universität Jena
Оригинални научни рад

Примљен: 1. 10. 2017.

Прихваћен: 27. 12. 2017.

\title{
КАРНЕВАЛИЗАЦИЈА ЕПСКОГ ЈУНАКА - „ПУТ АЛИЈЕ ЂЕРЗЕЛЕЗА” И „КРАЉЕВИЋ МАРКО ПО ДРУГИ ПУТ МЕЂУ СРБИМА”
}

\begin{abstract}
У овом раду се разматрају приповетке „Пут Алије Ђерзелеза” (Иво Андрић, 1920) и „Краљевић Марко по други пут међу Србима” (Радоје Домановић, 1901) у светлу теорије карневализације Михаила Бахтина. По његовој теорији карневализујући поглед је неопходан за слободу, да се супротставља важећим нормама, па и традицијом устаљеним представама. У том погледу су ове приповетке врло сличне. У њима аутор демитизује јунака, декомпонује ореол и кодекс јуначког понашања, подвргава га амбивалентном карневалском смеху. Гротеска, али и комично и трагично се у њима прожимају. Заједно са тиме аутор мотивише читаоца да рефлектује узроке карневализације.

Поред свих сличности, приповетке показују и разлике у вези са ауторским ставом према свом јунаку. Разарајући митску истину, Андрић у лику Алије Ђерзелеза више открива нагонску страну, несрећан пут људског бића, док Домановић у трагикомичним доживљајима свог јунака жели да разобличи морални пад, лицемерје и полтронство својих савременика.

Кључне речи: Алија Ђерзелез, Краљевић Марко, демитизација јунака, карневалски
\end{abstract} амбивалентан смех, ауторски став према јунаку, Иво Андрић, Радоје Домановић.

\section{I Епски јунаци и књижевни јунаци}

Марко Краљевић и Алија Ђерзелез су епски јунаци подједнако великог значаја; оно што је Краљевић Марко Србима, то је Алија Ђерзелез муслиманима. У епским песмама и легендама карактерише их јуначка слава, ореол хероја, сила и моћ; они су свемоћни и не знају за препреке; народ их види као борце натприродне снаге, као узвишене, митске личности и заштитнике у невољи, но у исто време и као примере који служе етничкој и националној идентификацији. Стога није изненађујуће што су неки од писаца њима пос-

*gabriella.schubert@gmx.de 
ветили своја дела. Као јунаци књижевних дела појављују се, између осталог, у Андрићевој приповеци „Пут Алије Ђерзелеза” (1920) и у приповеци Р. Домановића „Краљевић Марко по други пут међу Србима” (1901). У њима су, међутим, приказани у сасвим другом светлу, по Бахтиновој теорији можемо да назовемо карневализацијом.

Наративно језгро у њима представља повратак средњовековног епског јунака у своју земљу. Тиме је унапред опредељена демитизација, која код читаоца може да изазове амбивалентан став: смех и истовремено мотивацију за критично размишљање о узроцима тога.

\section{II Колективно памћење епског јунака и стварност модерне}

По Бахтиновој теорији карневализујући поглед у књижевности је потребан да се из друге, прочишћене перспективе сагледа живот са свим својим нормама, ограничењима и традицијом успостављеним представама (Бахтин 1978: 80). Тај поглед га ослобађа од „fanatizma i kategoričnosti, od elemenata straha i zastrašivanja, od didaktičnosti, od naivnosti i iluzija, od rđave jednostranosti i jednoznačnosti, od glupe bučnosti” (Бахтин 1978: 138).

У Андрићевој и Домановићевој приповеци карневализација је резултат сукоба предања и колективног памћења о епским јунацима са стварношћу савременог свакодневног живота, распетости између старих идеала јунаштва епских времена и менталног стања људи у модерни, у којој важе друге норме у друштвеним односима, тако да традиција често ни као памћење више не постоји.

Са појавом Алије и Марка Краљевића у нарацији је присутна и легенда која их прати. Андрић о Ђерзелезу обавештава:

Пјесма је ишла пред њим. На бијелу коњу крвавих очију, он је јахао раванлуком, црвене су ките биле бијелца по очима, а дуги чистим златом везени чевкени на Ђерзелезу сјали су и поигравали на вјетру (Андрић 2004: 257).

Домановић конципира једну експозицију у којој успоставља везу са предањем по којем Марко Краљевић није умро, него је само заспао и пробудиће се кад дође време за подизање опште борбе за ослобођење српског народа.

Марко се обраћа Богу да га врати у живот пошто му је досадило кукање: „’'Јао, Косово!' ... 'Косово тужно!' ... 'Куку, Лазо!'” [...] „,'Устани, Марко!'” [...] „’Погледај, Марко, сузе!'” [...] „'Шта чекаш, Марко?” (Домановић 1901: 5). И Бог га шаље на земљу са свим његовим епским атрибутима. Марко: „Гледа Шарца. Јест, Шарац онај исти. Гледа топуз, сабљу, одело, све исто, сумње нема. Маши се тулумине" (Домановић 1901: 6).

Враћањем јунака међу људе, развија се једна радња коју можемо упоредити са карневалском игром. Већ на почетку Андрићеве приповетке добијамо такав утисак у хану у ком се скупља „чељад која су запела на свом путу”: „поваздан се чује само шала, смијех, пљесак, глас дефа и шаргије или зурне, 
звук коцака на сухој дасци од игре шешбеш, роктање и цика путене и беспослене чељади" (Андрић 2004: 256-257).

Кад се, међутим, Марко појави на земљи, ситуација је мало другачија. Нико га не запажа, само се један велосипедиста уплаши од његовог чудног изгледа, а Марко се, „опет, највише препаде од чудна начина путовања и помисли да је каква утвара; али се ипак реши да се с тим чудовиштем пусти у борбу" (Домановић 1901: 6).

\section{III Карневалска атмосфера и смех}

Анахронизам, односно контакт средњовековног епског јунака са модерним друштвом аутоматски ствара један оквир у коме владају конфузија, дезинтеграција и амбивалентна атмосфера. Прожимају се комика, гротеска, као и трагика, меша се свето са профаним, високо са ниским, велико са најмањим, мудро са глупавим. Присутан је један, по Бахтиновим речима, „дубоко контемплативан и универзалан" смех (Бахтин 2000: 116) који има деконструктивну а у исто време и продуктивну функцију која искључује сваку догматску озбиљност, као и апсолутну тачку гледишта, остављајући закључак пресуди читаоца.

Рушењем митског света и јуначког кодекса понашања легендарни ликови постају обични смртници; дистанца и респект околине према њима више не постоји. Они су учесници у представи у којој, по Бахтиновом објашњењу, уместо поларизације извођача и посматрача превлада њихова интеракција у фамилијарној атмосфери.

Пошто епски јунаци нису прилагођени условима живота које налазе у својој околини, стално наилазе на сметње и блокаде, западају у смешне и гротескне ситуације у којима су све више понижени и подвргавани амбивалентном карневалском смеху.

Епски јунаци својим земљацима делују ексцентрично и анахроно, они су смешни и трагични у исто време - трагични, јер њихово достојанство страда; с друге стране, до извесне мере одају утисак добродушности.

\section{Алија Ђерзелез}

Ђерзелез се појављује са ореолом јунака крвавих очију, одевен у златну доламу, јашући белог коња. Но, кад сиђе с коња, ишчезне страх и респект околине према њему. Андрић то наглашава:

Кад сјаха и пође према капији, виђело се да је необично низак и здепаст и да хода споро и раскорачено као људи који нису навикли да ходе пјешице. Руке су му биле неразмерно дуге. Назва набусито и нејасно мерхаба и уђе у кахву. Сад кад је сишао с коња, као с неког пиједестала, поче да се губи страх и респект и, као да се изједначио с осталима, почеше му прилазити и започињати разговор (Андрић 2004: 257-258). 
Његове телесне слабости су повезане са слабостима понашања: без престанка пије, наређује и пева, почиње и да се зноји. Пијани јунак све више пада у занос, а

[...] Алчаци се ругају с њим без имало страха и обзира. Богдан Цинцарин [...] пјева, пјева, а Ђерзелезу се чини да му душу вуче и да ће, сад на̀, издахнути од превелике снаге или превелике слабости (Андрић 2004: 259).

Води га нагон, банчи и пије, коцка се, очаран је женском лепотом и није у стању да рационално размишља. Очајнички тражи љубав: „бјесно и неодољиво зажеље кауркињу, да је види, да је има, да зна на чему је, или иначе да побије и поломи све око себе” (Андрић 2004: 262), међутим, његова жеља се сукобљава са начином којим покушава да дође до њене реализације; он је груб, неспретан и простодушан. Постаје карикатура. Не може да схвати да га Венецијанка не жели. У другом делу хоће да освоји прелепу Циганку Земку. Гледајући Земку, он је ван себе:

Ђерзелез сједи и гледа, топи се и шири руке - збогом памети! - понијело га весеље и љепота и оне димије од цамбаса што лепршају као барјак и мешају се са врховима борова и с ведрим небом. Као да се његовој жалости прохтјело да се сва одједном прометне у обијест и весеље (Андрић 2004: 268).

Око њега се игра коло, смеје и пева се, а Алија само још ниже пада:

Распасао се, па му спадају и борају се чакшире, а ионако кратке ноге му изгледају још краће и још дебље; отпасао му се појас од ибришима вишњеве боје па се вуче за њим, поливен ракијом и умрљан пепелом. Једва се држи на ногама, кривуда и смјера час лијево, час десно (Андрић 2004: 269-270).

У трећем делу поново тражи жену, између осталог, „кауркињу” Катинку, девојку чија лепота се опева у песмама. Угледавши је, Ђерзелез је поново „ван себе”: „Као и увијек кад би угледао женску љепоту, он изгуби у тили час сваки рачун о времену истинским односима и свако разумијевање за стварност која раставља људе једне од других" (Андрић 2004: 274).

Катинка му међутим остаје недостижна. Ђерзелеза то потпуно избацује из равнотеже: „Каква је ово шала опет? И какве су то жене до којих се не може као ни до Бога?” (Андрић 2004: 279).

На крају заврши у постељи проститутке Јекатерине. И поставља себи питање у унутрашњем монологу, које је уједно и основно питање читаве приповетке:

И још се једном јави мисао с којом је сто пута заспао, нејасна, никад докрај домишљена, а увредљива и јадна мисао: зашто је пут до жене тако вијугав и тајан, и зашто он са својом славом и снагом не може да га пређе, а прелазе га сви гори од њега? Сви, само он, у силној и смијешној страсти, цио свој вијек пружа руке као у сну. Шта жене траже? (Андрић 2004: 281). 


\section{Марко Краљевић}

За разлику од Алије Ђерзелеза, Марко Краљевић је, после повратка на земљу, уверен да се и даље налази у јуначкој средини и није спреман да процени реалну ситуацију. Он се упушта у јуначку борбу са велосипедистом сматрајући га за опасног противника:

Попи још један леген вина, а дође крвав до очију, један даде Шарцу да попије, па онда врже тулумину у трави, самур-капу намаче на очи, и узјаши Шарца, који већ беше од пића крвав до ушију. Врло се јунак расрдио, и рече Шарцу: „Ако л’ ми га, Шаро, не достигнеш, сломићу ти ноге све четири!” (Домановић 1901: 6-7).

Разлог његовог повратка међу Србе је њихово вековно кукање и молба да се највећи српски јунак врати и освети Косово. Марко ту молбу дословно схвата, али узалудно тражи Србе који су га звали. У модерно време нестала је свест о јунаштву и о јуначкој храбрости, родољубивости, па чак и о некадашњем значењу родољубиве реторике. Позивање на јунаштво је постало фраза која ништа више не значи осим китњастог стила у реторици.

Марко је исто тако груб, неосетљив и бескомпромисан, мисли и делује на агресиван, екстреман начин. Као и Алија Ђерзелез, без престанка пије вино и љути се ако му се жеља не испуни одмах. Спреман је да у следећем моменту крене у двобој са сваким кога сретне на улици. Очекује га читав низ епизода у којима све ниже пада са престола јунаштва у стање бедног, трагикомичног лика. Механџију удари дланом по образу и помери му три здрава зуба. Жандарме, који му се приближе да га ухапсе, убије.

Тако доспева и у тамницу. Ту га онда потпуно физички преобразе: ошишају га и обрију, окују у тешке окове, обуку у бело одело и спроведу у Београд. Марко се најпре чуди, али постепено свикне на нове прилике и најзад се мирно преда судбини. По речима приповедача, почиње да се бави „корисним” пословима: носи воду, залива баште, плеви и полива лук, учи да прави бритвице, четке, кудеље и друге ствари. Након пуштања на слободу, он и даље тражи пут како да испуни своју мисију. Један Србин му каже: „Какво Косово на ове оскудне године?! Кошта то много! Велики је то трошак, мој брате!...".

Кога год сретне у Београду, тај брзо заврши разговор с њим и каже: „Журим у канцеларију! Сервус, Марко!”.

Уместо да задобије земљаке за свој циљ, застрашује их. Чуди се како се свет изменио, чуди се што Срби беже од њега, али ментално није у стању да препозна ситуацију и да схвати колико је његово понашање потпуно депласирано.

Највеће разочарање доживљава у „патриотском збору”, где сопственим ушима чује како „патриоти” позивају великог јунака Краљевића да им помогне. Кад се Марко спреми да им ту жељу испуни, опет га разочарају. Председник му каже: „То се тако говори да је стил лепши, китњастији. Старински си ти човек, брате слатки, па не знаш многе ствари! Наука је, драги мој, далеко дотерала". 
Последњи Марков покушај да буде користан на месту пандура опет је промашај, јер једном приликом избије свом капетану три зуба. Ухвате га после дугог окршаја и спроведу у лудницу на преглед где Марко заврши свој боравак на земљи. Кад поново изађе пред Бога, правда се: „Боже ми опрости, али ми се чини да и нису моји потомци, иако мене певају, него да су потомци оног нашег Суље Циганина”.

\section{IV Контрастирање гестова и језика}

Ефекат карневализације у разматраним приповеткама се постиже не само контрастирањем садржајних фактора него и контрастирањем гестова и језика главних протагониста. Епски Ђерзелез није само физички нескладан већ и својим гестовима и говором постаје смешан: није у стању да се изрази и врло неспретно води разговор са људима у својој околини: „ширио би своје дуге руке и кружио прецрним очима, као у кунића (Андрић 2004: 258). Његова прича о љубави је смешна, „казујући више рукама него ријечима” (Андрић 2004: 260). Насупрот томе, његови поступци су описани формулама из епских песама као: „Лети Ђерзелез као крилат”, „- Ха, потеци, Ђерзелезе, соколе! - Аферим, кењчино!” (Андрић 2004: 261).

Још јасније него Алије Ђерзелеза, дехероизацију Марка Краљевића прати контрастирање у поступцима и у језику. Марко се служи епским језиком, прича у десетерцу:

„Ој Бога ти, незнани јуначе

Чиј’ су ово пребијели двори.” (Домановић 1901: 8)

Он је оцртан истим хиперболизујућим потезима који су познати из јуначких песама, али који у приликама на крају 19. века делују апсурдно. Најочитије се то показује у опису судског процеса против њега који траје две године и пролази кроз све судске инстанце.

У сусрету са судијом, у среској канцеларији, сударају се два различита језичка нивоа као последица два различита мишљења и виђења света. „Питам, јесте ли чиновник, трговац, или радите земљу?, пита судија, а Марко одговара: - Није мени ни бабо орао, пак је мене хлебом одранио!”.

Марко свој исказ даје у десетерцу:

Ја ћу почи, ако нико неће,

Хоћу поћи макар доћи нећу,

Отићи ћу граду Цариграду,

Погубићу цара од Стамбола.

Срески капетан чита Марку тачке оптужнице и пита га за браниоца, а Марко, као да се налази у јуначком двобоју, дозива Милоша Обилића да га брани. Исто тако, када му у „патриотском збору” кажу да су му потребни жиранти, Марко епским десетерцем дозива побратиме. „Патриоти” му на то 
иронично кажу да су му довољна само два. У Марков говор Домановић је уткао целе стихове узете из познатих епских песама. Тако Марко, када у приповеци разговара са Шарцем, каже:

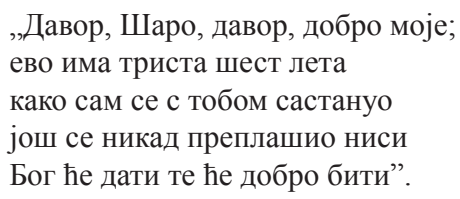

\section{V Подстицај аутора за карневализацију}

После свега реченог поставља се питање: шта је подстакло Андрића и Домановића да карневализују епског јунака и коју поруку тиме желе да пошаљу читаоцима?

У тражењу одговора можемо кренути од времена када су написане приповетке, а то је почетак 20. века. Било је то време европеизације, која је у Србији, као и у другим земљама Балкана, почела већ у другој половини 19. века и постала још интензивнија почетком 20. века. То је време такозваног повратка Балкана у Европу са следећим главним циљевима: брисање свега шта је припадало османлијској прошлости и преузимање западних узора у свим сферама јавног и свакодневног живота. Тиме је преоријентација на културном и социјалном плану постала неопходна, али је у исто време наилазила на многе отпоре. Европски узори су били преузети у видљивим културним манифестацијама живота, између осталог у архитектури, техници, администрацији и науци, али мишљење и понашање човека у међуљудским односима и емотивним везама нису се мењали. Иако су вредносни систем прошлости, традиција и етика епских песама и патријархалног мишљења изгубили своју снагу, нови вредносни систем још није био устаљен. Ова распетост између мишљења и понашања патријархалног човека с једне, и захтева модерног времена с друге стране, показана је у оба дела. У њима се суочава лик јунака са сликом коју савремени људи имају о њему.

\section{Андрићев став према свом јунаку}

Ауторски став према главном јунаку у разматраним приповеткама је сличан, али и различит у исто време.

Полазна тачка у обе приповетке је епска слика. У Андрићевој књижевној визији епско језгро и смисао предања, међутим, добијају психолошку димензију. Ђерзелез је избачен из света мита и легенде и убачен у реалан свет, где је приказан као личност без јуначких мисли и жеље, као људско биће са физичким и менталним слабостима. Андрића сад више и не интересује лик јунака и јуначких подвига, него у лику Алије Ђерзелеза открива скривене, нагонске стране људске природе, његове жеље и снове, емоције и идеале, ломове и поразе, тиме и страдање (у том смислу в. Даловић 2014). Ђерзелеза 
покреће тежња за љубављу и друштвеним признањем, али не успева да то оствари због својих физичких и менталних мана. Није у стању да правилно оцени себе, своје способности и мишљење, као ни захтеве других, посебно захтеве жена према мушкарцу.

Епски јунак узима дио истине за цијелу истину и покушава да живи по њој, тако нам дјелује гротескно, а истина коју је прихватио показује се као лаж - он носи у себи епски систем вриједности и сматра да му као јунаку припада најбоље, а баш због тога испада смијешан. Несклад између изгледа и идеје о себи овдје је основни извор смијеха (Даловић 2014: 211)

Може се рећи да Алија није био дорастао модерном, индивидуализованом животу. Носећи у себи дух епских времена, мислио је да као јунак може да осваја сваку, и најлепшу жену, али тај циљ хоће да постигне силом, епском снагом која често губи сваку меру. Стога је несрећан и трагичан. Он пати што не успева да оствари себе као мушкарца и као признату и цењену личност. Венецијанка је за њега недоступна; Земка се поиграва са њим, скрива му се и бежи; а Катинка постаје видљива само за тренутак, кроз капију и никад више. Његова потрага завршава се у наручју давнашње познанице, сарајевске проститутке Јекатерине, једине жене ,до које се иде право”.

По мишљењу Сузане Даловић (2014: 207) приповедачки став карактерише „дух супериорне симпатије да иза сваког Ђерзелезовог поступка тражи човјека као мјеру ствари.” Карневализација је по њеном мишљењу

[...] послужила Андрићу да се нека важна питања о човјеку, његовом положају у савременом свијету и психолошкој страни људске природе из свијета филозофских идеја пренесу у свијет непосредног, конкретног чулног контакта ликова и догађаја. Његов пут није пут достојанствених и узвишених јуначких подвига и херојске славе, то је пут несрећног човјека модерног сензибилитета (Даловић 2014: 207; 213).

\section{Андрићев став из муслиманске перспективе}

Сасвим другачије оцењују ову приповетку критичари из муслиманске средине. Сматрају да Андрић свесно иронизује част и славу јунака бошњачке епске традиције. По њиховом мишљењу Андрић у свим својим делима муслимане Босне и Херцеговине представља на ружан, готово понижавајући начин, да је користећи њих, створио један стереотип који је изузетно штетан за Бошњаке. Између осталог, аутор Дурић приповетку о Алији Ђерзелезу поставља у једну линију са укупним делом И. Андрића, које почиње са његовом дисертацијомРазвојдуховногживотау Босниподутииајемтурскевладавине. По мишљењу Дурића (Дурић 1998) Андрић је већ у овом раду имао намеру да докаже штетно дејство османлијске владе за социјално стање становништва Босне и Херцеговине, да раздваја хришћане од Турака и да покаже инкомпатибилност турско-исламског и босанско-муслиманског начина живота.

Без жеље да уђемо у опширнију дискусију, која захтева посебну расправу, сматрам да је Андрић без икаквих идеолошких оптерећености користио ликове као што је Алија Ђерзелез са циљем текстуализације традиције 
и културне средине Босне и Херцеговине. Његово питање „Зашто је пут до жене тако вијугав и тајан?” је питање општељудских, а не односа између припадника различитих вероисповести; карневализујући поглед на те односе приморава читаоца да размишља у том правцу.

\section{Домановић и његов јунак}

Док Андрић у лику Алије Ђерзелеза открива нагонску страну, несрећан пут људског бића, Домановић у трагикомичним доживљајима свог јунака жели да разобличи морални пад, лицемерје и полтронство његових савременика (уп. Шуберт 2006). Он је био син сеоског учитеља и одгојен је у духу народне поезије. Познато је да је волео сеоско-патријархални начин живота и епску поезију до те мере да је својим пријатељима често писао писма у десетерцу. У исто време је био чврсти присталица слободе и противник свих видова тираније аутократије. „Краљевић Марко по други пут међу Србима” је писан под импресијом тадашњих друштвених прилика и као отпор према насиљу режима последњих краљева из династије Обреновића, Милана и Александра, као „манифест политичких догађаја” који су, по сведочењу Јована Скерлића, надахнули његове најбоље политичке сатире. Почетак 20. века у Србији је обележен као време заоштравања сукоба између режима и опозиције, јачање бирократског апарата, ограничавање слободе говора и окупљања, као и увођење полицијског терора. Када је због најаве женидбе краља Александра с Драгом Луњевицом Машин премијер Владан Ђорђевић дао оставку, краљ је образовао тзв. „свадбено министарство”, чији је главни циљ било омогућавање краљеве свадбе и стишавање узбурканих политичких страсти у земљи. У то време, у јулу 1900. године Радоје Домановић је постао писар у Државној архиви, а у марту 1901. писар у Министарству просвете и црквених дела. Међутим, Домановићев непомирљиви опозициони став не само да се није ублажио већ је постајао све израженији. У том периоду он у Српском књижевном гласнику објављује неке од својих најзначајнијих сатиричних приповедака: поред поменуте приповетке „Краљевић Марко по други пут међу Србима”, још и „Вођу” и „Страдију”. Домановићева сатира разара власт династије Обреновић, илуструје у карикатури ту власт и предаје је исмевању, суду народа. Сатира га је до извесне мере и бранила од цензуре. Домановић је својом сатиром ударио највише по пасивности и робовању филистарском конформизму, по трпљењу силе и насиља, по фразеолошком и демагогијском родољубљу, по пандурству, полтронству и издаји витешке традиције. У овом контексту Глигорић (1956: 347) запажа да је Домановић пре свега желео да брани витешку традицију и да је имао некритичан однос према патријархалности у којој је он видео друштвену основу националног живота Србије. Према њему, Домановић је и негирао европеизацију која је надирала у културни и друштвени живот Србије.

У разматраном делу, међутим, у центар је постављен напад на лажни патриотизам и помереност норми ван етичких, хуманих и логичних граница, изопаченост и апсурдност поступака и схватања, однос стварности пре- 
ма традицији, која је изгубила функцију. Радоје Домановић је овом сатиром погодио у језгро хвалисавог и лажног родољубља. У опису судског процеса против Марка јасно се осећа критички став Домановића према бирократији и ситничарском поступку судских органа тог времена. Саркастично удара по пандурима и онима који, било из користољубивости, било из полтронства или заузети ситним бригама - у граду својом каријером или на селу радом на њиви - служе понижавајућем режиму. Херојско-епској слици народне поезије у чијем су светлу израсли борци за слободу, Домановић супротставља сићушну и ниску прозаичност садашњице обележене празним хвалисавцима који се у свакој прилици позивају на Краљевића Марка и Косово, али кад својим делом то треба да посведоче, они се као мишеви скривају под скут режима. Овакво родољубље типично је за апсолутистички режим који заједно са потчињеним народом и празном реториком покрива унутрашње слабости.

\section{ЛИТЕРАТУРА}

Андрић 2004: И. Андрић, Пут Алије Ђерзелеза, у: И. Андрић, Мост на Жепи, Изабрана дела I-X, Београд: Дерета, 256-281.

Бахтин 1978: M. Bahtin, Stvaralaštvo Fransoa Rablea i narodna kultura srednjeg veka $i$ renesanse, Beograd: Nolit.

Бахтин 1986: M. Bakhtin, The Bildungsroman and Its Significance in the History od Realism (Toward a Historical Typology of the Novel), in: M. M. Bakhtin, M. Holquis, \& C. Emerson (Eds.), Speech Genres and Other Late Essays, Austin, 10-57.

Бахтин 1989: M. Bahtin, O romanu, Beograd: Nolit.

Бахтин 1991: M. Bahtin, Autor i junak u estetskoj aktivnosti, Novi Sad: Bratstvo-Jedinstvo.

Бахтин 2000: M. Bahtin, Problemi poetike Dostojevskog, Beograd: Zepter book world. Бахтин 2010: M. Bahtin, Ka filozofiji postupka, Beograd: Službeni glasnik.

Вученов 2008: Д. Вученов, Генеза Домановићеве сатире, y: М. Станојевић (ур.), Лако Перо Радоја Домановића, Крагујевац: Кораци, 65-77.

Глигорић 1956: В. Глигорић, Српски реалисти, Београд: Просвета.

Даловић 2014: С. Р. Даловић, Алија Ђерзелез у свјетлу карневала, Филолог V, 2014/9, Бања Лука, 205-214.

Деретић 1983: Ј. Деретић, О Радоју Домановићу, Историја српске књижевности, Београд: Нолит.

Домановић 1901: Р. Домановић, Краљевић Марко по други пут међу Србима, Данга, Вођа, Београд.

Дурић 1998: R. Durić, Der bosnische Held Djerzelez in der Historiographie, in epischen Liedern und in der literarischen Bearbeitung von Ivo Andrić, Zeitschrift für Balkanologie 34/1, 1-14. 
Максимовић 1999: Г. Максимовић, Домановићев смијех, Зборник Филолошког факултета Универзитета у Приштини, књ. 9, Приштина/Врање, 277-279.

Поповић 2008: Б. Поповић, Алегорична сатирична прича, $y$ : М. Станојевић (ур.), Лако перо Радоја Домановића, Крагујевац: Кораци, 11-59.

Шуберт 2006: Г. Шуберт, Домановићев Краљевић Марко по други пут међу Србима - сатира или политичка парабола?, Научни састанак слависта у Вукове дане 35/2, Београд 2006, 265-271.

\author{
Gabriella Schubert
}

\title{
KARNEVLISIERUNG DES EPISCHEN HELDEN - „PUT ALIJE ĐERZELEZA” UND „KRALJEVIĆ MARKO PO DRUGI PUT MEĐU SRBIMA”
}

\section{(Zusammenfassung)}

In diesem Beitrag werden zwei Erzählungen unter dem Aspekt der Theorie von Michael Bachtin zur Karnevalisierung betrachtet: „Put Alije Đerzeleza” [Der Weg von Alija Đerzelez] von Ivo Andrić, veröffentlicht 1920, und „Kraljević Marko po drugi put među Srbima” [Marko Kraljević zum zweiten Mal unter den Serben] von Radoje Domanović, veröffentlicht 1901.

Nach der Theorie von Bachtin ist ein karnevalistischer Blick erforderlich, um die Freiheit zu erlangen, sich geltenden Normen und durch Tradition festgefahrenen Vorstellungen zu widersetzen. Unter dieser Prämisse sind die beiden hier behandelten Erzählungen sehr ähnlich. In ihnen werden die epischen Helden entmythisiert; ihr Nimbus und Ehrenkodex werden dekomponiert und dem ambivalenten karnevalistischen Lachen preisgegeben. In beiden Erzählungen überlagern sich das Groteske, das Komische und das Tragische. Damit wird der Leser zugleich dazu motiviert, über die Ursachen der Karnevalisierung nachzudenken.

Trotz aller Ähnlichkeiten zeigen die beiden Erzählungen im Hinblick auf das Verhältnis des Autors zu seinem Helden auch Unterschiede auf: Indem er die mythische Wahrheit zerstört, sucht Andrić in der Gestalt von Alija Đerzelez eher die Leidenschaftlichkeit und die unglückliche Suche des Menschen nach Liebe und Anerkennung, während Domanović über die tragikomischen Erfahrungen seines Helden den moralischen Niedergang, die Heuchelei und Feigheit seiner Zeitgenossen entlarven will. 